\title{
Organization of knowledge in ayurveda medical systems: an analytical approach
}

C. K. Gamage ${ }^{1}$

\begin{abstract}
Organization of Knowledge is directly designated as a field of study related to library and information science. According to this, Organization of Knowledge, is mostly practiced in the domain of library and information science, and has been largely the province of the construction of tools for the storage and retrieval of documentary entities. Organizing is helps to maintain the body of knowledge. There are different historical and theoretical approaches and theories regarding organizing knowledge. They are traditional approach, facet analytical approach, bibliometric approach and the domain of analytic approach etc. In this process, the generation of theory has moved from an epistemic stance of pragmatism to empiricism. Ayurveda the science of life has been treated as one of the oldest systems of medicine in the world. There are two main objectives of this study, to explore the organizational patterns of knowledge in Ayurveda System of medicine and to explore specialties of organizational patterns used for knowledge in Ayurveda medicine. This research is based on the survey method. Two types of survey methods were employed i.e. literature survey and field survey. Major Ayurveda classics were used as primary sources of literature in this research. This study confirms that the Ayurveda system of medicine has a systematic, methodical pattern of knowledge organization. It is therefore can be concluded that the knowledge organization in Ayurveda medicine has been done, not based on any other system available elsewhere or at any other period, but on their own system particular to it and is therefore unique.
\end{abstract}

Keywords: Organization of Knowledge, Knowledge Management, Ayurveda Medicine, History of Ayurveda Medicine, Oriental medical systems

Senior Assistant Librarian, Institute of Indigenous Medicine, University of Colombo

Email: ckgamage31@gmail.com, (iD https://orcid.org/0000-0002-1166-7017 


\section{Introduction}

From the beginning of mankind, every civilization has developed its own unique knowledge systems. These knowledge systems have been linked with their culture, languages, health care, education, environmental conservation and also dealt with their life style. The transformation from an agrarian to an industrial economy, and subsequently to the knowledge based society has to be considered as a result of the accumulation of knowledge and the advances in information and communication technologies. To maximize the value of knowledge it needs to be controlled, rebuilt and organized. Organization of knowledge lies under the broad concept of knowledge management.

All types of knowledge are products of the society and cultural environment in which it is created. Indigenous/Traditional knowledge, explicit knowledge and tacit knowledge, Tangible and Intangible Knowledge are some forms of knowledge. Indigenous knowledge, formulated by indigenous people or aboriginal tribes has been handed down from generation to generation for hundreds and thousands of years. It is a valuable asset for any country as it plays a vital role in making the nation more progressive and more dynamic. Explicit knowledge can be expressed in formal and systematic language but tacit knowledge is highly personal and hard to formalize. Tacit knowledge embedded in individual experience involves intangible factors such as personal and cultural beliefs, perspectives as well as skills, capabilities, expertise and the value system. According to sociological view, culture can be identified in two categories such as tangible knowledge and intangible knowledge. The things made by the people which can be seen physically are called as tangible knowledge and cultural heritage which cannot be seen and cannot be touched is called Intangible knowledge. At present, most of the countries have paid their attention to the protection of intangible cultural heritage.

Organization of Knowledge is directly designated as a field of study related to library and information science. According to this, Organization of Knowledge, mostly practiced in the domain of library and information science, and has been largely the province of the construction of tools for the storage and retrieval of documentary entities such as classification, cataloguing, indexing etc. There are different historical and theoretical 
approaches and theories regarding organizing knowledge, such as traditional approach, facet analytical approach, bibliometric approaches, analytic approach etc. In this process the generation of theory has moved from an epistemic stance of pragmatism to empiricism.

At a time where the importance of alternative medicine has gained momentum, this study attempts to reveal whether the organizational pattern of knowledge in the system of Ayurveda medicine is inherent to its own method or based on different theories that are found in the world.

\section{Research Objectives}

1. To explore the organizational patterns of knowledge in the Ayurveda system of medicine.

2. To explore the specialties in the organizational patterns of knowledge in Ayurveda medicine.

\section{Literature Review}

Universe of Knowledge, its Classification and Organization

In ancient times, the main objective of classification was the organization of knowledge. Various philosophers and scholars have introduced a number of methods for the organization of universal knowledge. The recognition of similarities, rational thinking and conceptual thinking are the three approaches used to make a structure for knowledge organization. Universal knowledge is linked with systems of knowledge which have been mapped out in different epochs of human history. At the beginning, classification was used to classify the human thoughts and the material world. It is the Western world that comes to the forefront when knowledge classification is considered. The Eastern world has also commenced this task simultaneously. Along these lines, it is vital to note that ancient Greece and the Vedic culture of India have been involved in classifying the Universe of knowledge. There are different historical approaches and theories about organization of knowledge.

\section{Conventional Methods of Organization of Knowledge}

The epistemology of the Vedic system of ancient India was perhaps the first knowledge organizational method of the Eastern world. It was adopted by 
the later epics, and the encyclopedia known as the 'Puranas'. The Bhagawath-Geetha adopted the knowledge organization in its systematic exposition, and so did the later 'Tantras'. The Vedic system has divided the Universe of knowledge into four categories, Dharma, Artha, Kama and Moksha, which categorization have spread in the Indian society. Any universe, whatever it be of human beings, or animals, or plants, or phenomena, or concepts of any kind, knowledge was classified based on these four values.(Kumar, 2004) The first main class, Dharma, is concerned with the preservation of society as a coherent organization and corresponds to the modern classes of law, theology, ethics and sociology. Artha, from the point of view of social wellbeing and happiness includes all applied sciences, natural as well as social. This is the social motive and pressure for the development of pure sciences. The third main class Kama comprises of all pure sciences, linguistics, fine arts and literature. The last class Moksha covers philosophy and subjects involving individualism par excellence. This Vedic system of knowledge is arranged in a systematic sequence and socio centered system.

Plato (428-347 A.D.) was the pioneer of Western philosophical knowledge classification. He has categorized his thoughts into three parts, logic, physics, and ethics. Plato's philosophical system displays similar features present in the Vedic system. Logic, Physics and Ethics gradually represent mind or philosophy (Moksha), Natural and applied sciences (Kama and Artha), Group behavior and Society (Dharma). It appears that Plato's system is the reverse of the Vedic system.

A very famous Greek philosopher Aristotle showed the empirical approach which was his classification based on existing Greek knowledge. His criteria for distinguishing the forms of knowledge were aims, subject matter and mode of enquiry, which produced a primary division of theoretical knowledge (for its own sake), practical knowledge (for the good of mankind) and productive knowledge (for making things). The subjects of Metaphysics and mathematics are included in theoretical knowledge, while political science, economics and law are included in the practical knowledge and Productive knowledge is covered by the subjects of fine arts, literature, natural science etc. 


\section{Medieval Methods of Organization of Knowledge}

There is a long history and closer examination of knowledge organization which shows that in the world, especially in India, more steps have been taken for knowledge organization, as much as in Western countries. This history goes back to pre-Buddhist era. Knowledge organization or knowledge classification was used in ancient times for organization of the society. According to this concept the Indian society was also divided into four groups viz. Brahmana, Kshasthriya, Vaishya and Shudra.

Epistemologists and philosophers have been interested in the idea of knowledge classification. Knowledge classification is also an essential section of knowledge organization and it is a structured system of categories used to collocate similar and separate dissimilar ones. In addition, these groups were arranged in a convenient way of sequences.

Francis Bacon lived in the early seventeenth century (in 1605) introduced a new concept to organize the universal knowledge. He divided the whole compendium of knowledge into three basic faculties, history, philosophy and imagination. According to his book titled "Advancement of Knowledge", he mentioned that this method was based on psychology centered classification. Bacon introduced three main perceptions such as Memory (history), Imagination (poetry), and Reasoning (philosophy). He tried to organize and classify the universal knowledge according to these categories. This scheme was widespread and influenced several classification schemes which had developed in the nineteenth and twentieth centuries. Ranganathan described this system as the 'Psychology Centered System' (Kumar, 2004).

\section{Modern Methods of Organization of Knowledge}

The new method presented by W.T. Harris in 1870, was a turning point in classification of knowledge, which was quite opposite to that of Bacon. The major arrangement of this method was philosophy, poetry and history. In 1876, Melville Dewey published the Dewey Decimal Classification (DDC) and Charles Cutter presented his Expansive Classification (EC). In 1895, based on the $5^{\text {th }}$ edition of DDC Paul Outlet and Henry La Fontaine (18691944) began the development of the Universal Decimal Classification. At the beginning of the $20^{\text {th }}$ century, the Library of Congress created its own 
classification (LCC) based on the main classes outlined in Cutter's Expansive Classification. Colon Classification (CC) was presented by S.R. Ranganathan in the early 1930s. Classification is mostly associated with arranging tangible items on the shelves but it is also utilized for the division of electronic resources. Classification schemes which are aimed at organization of knowledge, shelving and retrieving based on hierarchical order can be divided into several categories. They are purely enumerative schemes, almost enumerative schemes, almost faceted schemes, fully faceted schemes, almost freely faceted schemes etc. These hierarchical schemes begin with broad, top-level categories which were graded into a number of subordinate levels, moving from the general to the specific.

Meadows, A.J. (1991) the editor of "Knowledge and Communication" turned Aristotle's divisions of three primary forms into modern terms such as natural science, mathematics and metaphysics. Collingwood, R.G. (1924) created a different analysis without incompatibility. He proposed five innate forms of knowledge: Philosophy, science, history, art and religion. Benedetto Croce (1952) is a modern idealist philosopher who begins by dividing the activities of mind into knowing and doing. Needham (1964) pointed out the importance and ever increasing validity of communication of knowledge. All societies depend upon their very existence on the communication of knowledge. Before communicating any knowledge or knowledge systems, it is necessary to organize them properly.

The knowledge organization can be described as a conglomeration of actions to sort, arrange and utilize knowledge by means of classification and beyond. This includes acquisition, evaluation, description, representation, communication and utilization of knowledge. It also leans heavily on terminology organization (Satija, 2004)

Hjorland (2008) studied the narrow and broader meaning of Knowledge Organization (KO). It is about activities such as document description, indexing and classification performed in libraries, bibliographical databases, archives and other kinds of "memory institutions" by librarians, archivists, information specialists, subject specialists, as well as by computer algorithms and laymen. In the broader meaning $\mathrm{KO}$ is about the social division of 
mental labor, i.e. the organization of universities and other institutions for research and higher education, the structure of disciplines and professions, the social organization of media, the production and dissemination of knowledge etc.

Hjorland (2013) highlighted that the field of knowledge organization itself is based on different approaches and traditions such as user based and cognitive views, facet analytical views, numeric taxonomic approaches, bibliometrics and domain analytic approaches. These approaches and traditions are again connected to epistemological views, which have to be considered. Only the domain analytic view is fully committed to exploring knowledge organization in the light of subject knowledge and substantial scholarly theories.

Mai, J.E. (2014) argued that the classic tradition of classification theory is based on a modern view of the world. This includes the idea that classification can be a neutral and objective mirror of an already existing universe of knowledge. A postmodern theory of knowledge organization rejects this assumption and instead focused on the social praxis and the language of the community for which the knowledge organization is created.

\section{Methodology}

This research is based on the survey method. Two types of surveys were employed i.e. literature survey and field survey. For the literature survey, three major Ayurvedic medical classics named Charaka Samhitha, Susrutha Samhitha and Ashtanga Hardaya Samhitha were used as primary sources. Books written on related subject areas of Ayurveda medicine and organization of knowledge were also used as secondary sources.

The relevant data and information were directly collected from the field survey by using the interview method. A separate questionnaire had been developed in a very methodical way and in depth interviews were conducted with the help of a structured questionnaire. Colombo district in Western province and Anuradhapura district in North Central province were selected as the study areas of this research, considering the facts discussed below. 
Although the Colombo district is the most modernized and urbanized area and comprises diverse communities, those communities have a tendency to rely on the practice of Ayurvedic medicine. Existence of an Ayurvedic teaching hospital in Borella is a significant example. Another reason for the selection of Colombo district is the availability of Western medicine, with modern medical facilities in addition to Ayurvedic medicine. The citizens who live in the Colombo district form a heterogeneous community which consists of people from traditional villages, high, middle and lower class income groups, different religious and different ethnic groups.

The second district selected for this study is Anuradhapura, was the first kingdom of Sri Lanka and there are many historical records which offer proofs that there had been a medical system which has reached a very high standard in that kingdom. Even today, most senior and famous Ayurveda medical physicians practice in this province. There is a high complexity of medical pluralism in this district while urban, semi-urban and rural groups of people live there.

\section{Population and Sample}

Study population includes Ayurvedic medical practitioners who have been registered as medical practitioners $(n=2272)$ under the Medical Council of the Department of Ayurveda. All of these practitioners can be divided into two main groups in a very broad manner as institutionally trained practitioners and traditionally trained practitioners. Among these practitioners, 60 practitioners ( 3 participants in each category from one district) representing ten major categories of Ayurvedic medical system namely Kedum Bidum Vedakam (Local orthopaedics), Gedievana Pilika (Treatment of abscesses and tumors), Davum Pilissum Vedakama (Treatment of burns), Visha Vedakama (Treatment in toxicology), Es Vedakama (Ophthalmology), Mānasika Roga Vedakama(Psychiatry), Charma roga Vedakama (Dermatology), Bāla roga (Peadiatrics) Vātha Roga Vedakama (Nerves Diseases) and Sāmānya Sarvānga (Internal Medicine) were selected for the study, via purposive sampling. Accordingly, there are thirty practitioners from one district and altogether 60 medical practitioners were interviewed from the two districts of Colombo and Anuradhapura 


\section{Data Analysis}

The data collected through qualitative and quantitative methods were analyzed. The quantitative data played a secondary role in supporting the facts revealed by the qualitative data. The quantitative data collected were analyzed using the Statistical Package of Social Sciences (SPSS), while qualitative data were examined in the method of descriptive analysis accepted in social sciences.

\section{Results and Discussion}

Organization of Ayurvedic Medical Knowledge

Sri Lanka has a glorious history of more than 2500 years with a great cultural identity. It is a multi-national, multi-cultural and multi-religious country with a dominant of Buddhist culture. Ayurveda system of medicine is treated as one of the oldest medical systems in the world. It is not only a system of medicine but also a way of life and therefore it is truly holistic and an integral system of medicine. It has rendered an immense service to mankind for several decades. The continued existences and evolution of Ayurveda medicine has been influenced by the effective organization of such medical knowledge of the Ayurveda system.

The major classics of Ayurveda, Charaka Samhitha, Susrutha Samhitha and Ashtanga Hardaya Samhitha have also recorded that Ayurveda medical knowledge was comprehended by Lord Brahma himself. The Lord Brahma is considered to be the original profounder of Ayurveda. Hence, it is significant that the commencement of the organization of Ayurvedic medical knowledge goes to Divine level. According to the historical and legendary sources as well as Indian mythology, the creator of the world, Lord Brahma, had by himself comprehended Ayurveda medical knowledge, and then transferred this knowledge into one hundred thousand verses and thousand chapters.

\section{Concept of Tri Suthra or Tri Basic Approach}

The whole knowledge of Ayurveda system of medicine was initially organized according to three basic approaches or Trisuthra, coming from divine level to human level. The entire range of clinical activities is developed with the infrastructure of the tri basic approach. It comprises of 
the threefold components, Hetu, Linga and Aushada. According to the Ayurvedic classics, Indra, the Lord of the gods offered the whole knowledge of Ayurveda medicine comprising of three principles namely Hethu (etiology), Linga (symptomatology) and Aushadha (Medicine) in brief to the sage Bharadvaja. Here, Lord Indra had shown a special consideration for the wisdom of Rishi Baradvaja and had given him the whole system of Ayurvedic medical knowledge in brief as Tri Suthra. The Figure 1 explains it very clearly.

\section{Tri Basic Approach (Trisutra)}

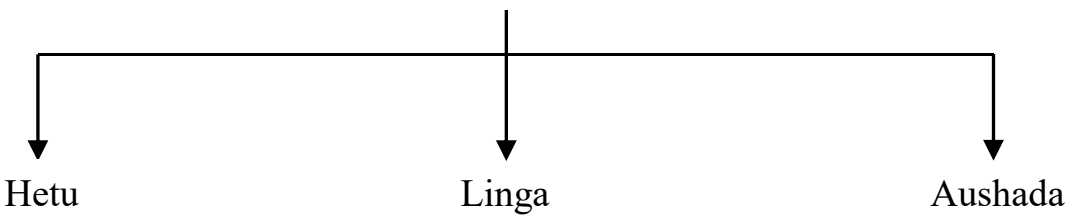

(Causative factors)

(The clinical factors)

(The medicaments)

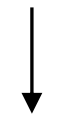

Pancha Nidāna

(Nidānādi Panchaka)

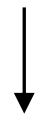

Clinical Methods or

Rogi Pareeksha

1. Shadvidha pareeksha

2. Ashtasthāna Pareeksha

3. Dashavidha

\section{Figure 1. Tri Basic Approach}

According to the figure 1, it is necessary to understand the Etiology or causative factor of the disease (Hethu) correctly, understand the signs and symptoms or clinical features of the disease (Linga) and for the diagnosed diseases prescribe suitable drugs or medicaments (Aushadha) for necessary treatment. 
Opinion on Ayurveda Medical Knowledge Organization

Table 1 demonstrates the satisfaction level of Organizational Patterns of Ayurveda Medical Knowledge among medical professionals in both districts. The majority of respondents, $(\mathrm{n}=33,55.00 \%)$ agreed that the existing organizational pattern of Âyurvedic medical knowledge is sufficient. None of the respondents opposed it and 27 respondents (45.00\%) expressed the view that they have no clear idea about the Ayurveda medical knowledge organization. (Table 1, and Figure 2)

Table 1. Opinion of Ayurveda Medical Professionals on Ayurveda Medical Knowledge Organization

\begin{tabular}{lrr}
\hline $\begin{array}{c}\text { Satisfaction Level of } \\
\text { Organizational Patterns of } \\
\text { Ayurveda Medical } \\
\text { Knowledge }\end{array}$ & Frequency & Percentage \\
\hline Yes & & \\
No & 33 & $55.00 \%$ \\
No clear Idea & 0 & $0.00 \%$ \\
Total & 27 & $45.00 \%$ \\
& 60 & $100 \%$ \\
\hline
\end{tabular}

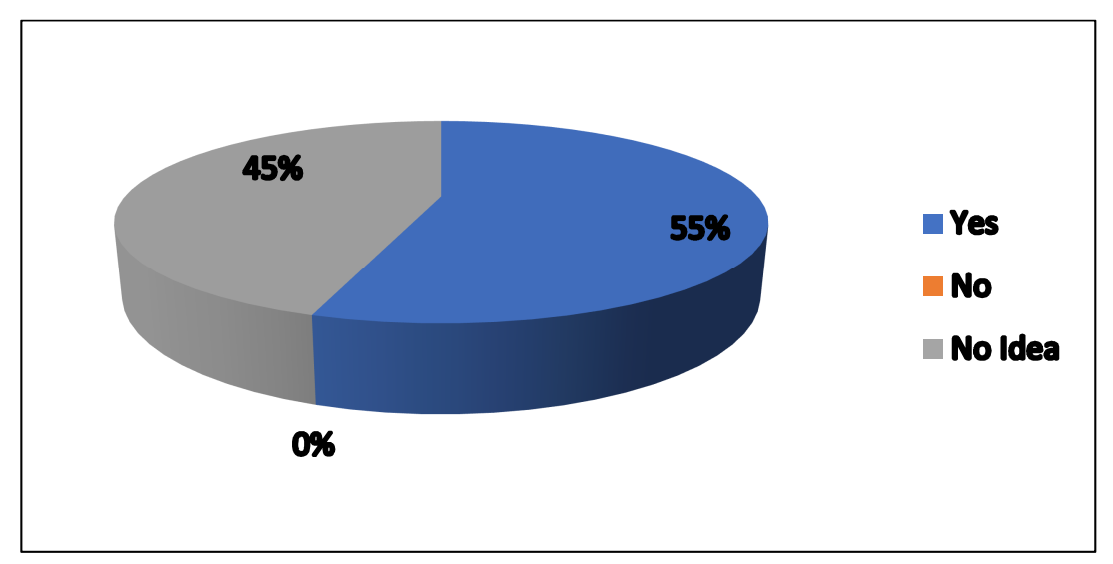

Figure 2. Opinion of Ayurveda Medical Professionals on Ayurveda Medical Knowledge Organization 


\section{Sub Divisions of the Knowledge of Ayurveda Medicine}

As regards the historical and textual evidence, Ayurveda medical knowledge commenced at the divine level and was transmitted from divine level to human level. This knowledge transmission occurred after organizing and arranging the required knowledge in a very methodical way. According to that, Lord Indra had given this knowledge to Rishi Bharadvaja in brief as Tri Suthra, and thereafter knowledge of Ayurveda medicine had been divided into eight sub divisions, considering the short life span of human beings and as well as the limited intellectual capacities. Therefore considering these two facts, Lord Indra had given the whole knowledge of Ayurveda medicine to Rishi Bharadvaja with its eight sub divisions. (Charaka, 2017, Sutra, Version

2) This can be considered as the second organizational pattern of Ayurvedic medicine and it is as follows;

1. Kaya Chikithsa (Internal Medicine) - Kaya means body and mind both. Kaya Chikithsa deals with generalized systemic disorders.

2. Salakya Tantra (Ophthalmology and Otorhinolaryngology) -This sub division is concerned with the management of diseases of the organs in the head i.e. ear, eye, mouth, nose etc. and diseases of the supraclavicular region.

3. Shalya Tantra (Surgery) - This branch deals with the extraction of foreign bodies and also deals with the use of blunt and sharp instruments, alkali treatment, cauterization as well as diagnosis and treatment of wounds and surgical conditions.

4. Agada Tantra (Toxicology)- Agada Tantra deals with the signs and symptoms and also the management of various poisonings such as with bites of snakes, insects, spiders, rats etc. and also other poisonous substances.

5. Bhutha Vidya (Psychiatry) - This sub division of Ayurveda deals with the management of psychiatric disorders and also deals with the treatment of such illnesses by exorcism and offerings to gods.

6. Kaumarabrithya (Paediatrics) - Deals with both preventive and curative aspects of pediatrics.

7. Rasayana Tantra (Geriatrics)-This sub division deals with the methods of maintaining youthfulness, increasing longevity, promoting 
life - span, intellectual capacity and strength as well as eliminating diseases.

8. Vajikarana Tantra (Science of Fertility and Virility) - This branch deals with Administration of aphrodisiacs, and also maintaining the vitality of the sperms and with spermatogenesis.

With regard to the field survey conducted among the Ayurveda medical practitioners in both districts (Colombo and Anuradhapura), the majority of respondents, $33(55.00 \%)$ out of 60 , their responses in relation to the organization of Ayurveda medical knowledge are satisfactory. The opinions they expressed about the organization of Ayurveda medical knowledge are shown in figure 2.

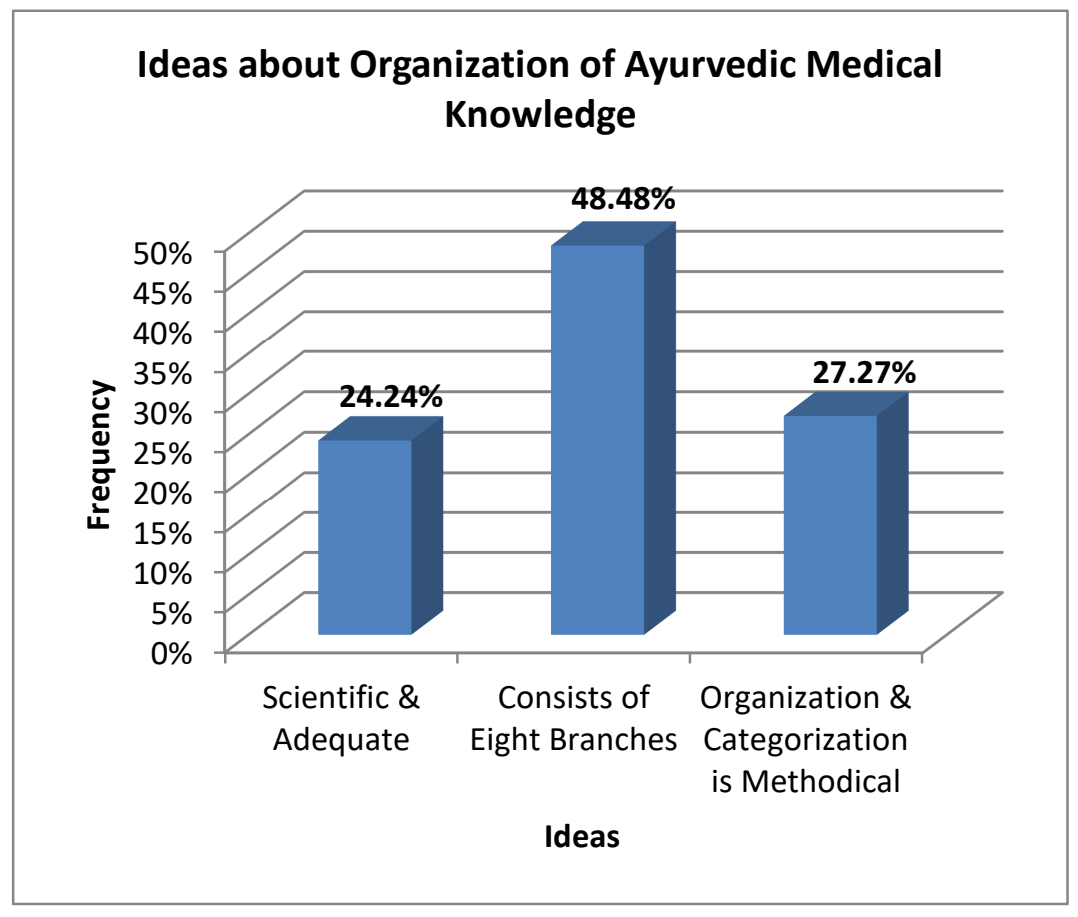

\section{Figure 3- Ideas about Organization of Ayurveda Medical Knowledge}

The highest number of respondents, which is 16 out of 33, expressed that the "Ayurvedic medical knowledge consists of eight branches". It reaches $48.48 \%$. The second group of respondents was of the opinion that "Ayurvedic medical knowledge organization and categorization was 
methodical." This idea is stressed by 9 practitioners. The least number of respondents, only eight (8) out of 33 respondents held the view that "Knowledge organization is scientific and adequate" The above three opinions expressed by both medical practitioners in two districts are illustrated as above.

\section{Development of Ayurvedic Traditions}

It was observed that eight sub divisions of Ayurveda medical knowledge further developed into two traditions, namely,

1. The Tradition of Kaya Chikithsa (School of Physicians) and

2. The Tradition of Shalya (The School of Surgeons) has taken place.

Rishi Bharadvaja was the profounder of school of Physicians and Acharya Susrutha leads the School of Surgeons. Hence, Ayurveda medical knowledge flowed along these two traditions from its beginning to the present, and according to that a separate Gurukula systems developed. The main classic of the School of Physicians is Charaka Samhitha and it was reported that Lord Brahma gave the knowledge of Kaya chikithsa to Rishi Bharadvaja. Susrutha Samhitha is the core book of the tradition of Shalya and it belongs to the School of surgeons, which was handed over from Lord Brahma to Lord Dhanvanthari.

\section{Disciples of Ayurveda Medicine}

Existence of any knowledge system or discipline, is based on several main factors viz. its commencement, gradual improvement, transmission, utilization etc. Even at present, the Ayurveda system of medicine is being highly utilized for the betterment and healthiness of human beings. The gradual growth of generations of students and researchers and also their research and publications are the other factors of the existence of this discipline.

Charaka reported that, Punarvasu alias Atreya, who was one of the direct disciples of Bharadvaja, is the preceptor of Agnivesa. There was a generation of students who have followed the Athreya tradition (sampradaya). Charaka reported it as, "Then Punarvasu, friendly to all and having compassion for all creatures expounded the sacred science of life to his six disciples. Subsequently these disciples viz. Agnivesa, Bhela, 
Jatukarna, Parasara, Haritha and Ksarapani followed his instructions." (Charaka, 2017, Sutra, Version 30- 31, p. 23)

\section{Research and Publications in Ayurveda Medicine}

Writing monographs by the most knowledgeable persons or students who are finalizing their student career theoretically and practically is the next step directly affects the organization of Ayurvedic medical knowledge. In Athreya tradition, Agnivesha has written Agnivesha Tanthra. According to modern educational concept, this book is like a thesis as regards the modern advanced educational curriculum in universities, thesis has to be presented in a professional forum and accepted. Long before such a concept originated, Agnivesha, had presented his book to the professional unit comprising a group of scholars and sages. The book was accepted with much pleasure by clapping hands after reviewing and conforming its accuracy, relevancy and richness of Ayurveda medical knowledge.

From then onwards, the art of writing Ayurveda medical books has gradually developed. Thus, a large number of books have been written by scholars. The excellent three books named Charaka Samhitha, Susrutha Samhitha and Ashtanga Hardaya Samhitha called Vridhathraya become prominent among all the other books. Rishi Charaka has edited the Agnivesha Thantra which was written by Agnivesha and after that it was introduced as Charaka Samhitha. Susrutha Samhitha of Rishi Susrutha, Ashtanga Hardaya Samhitha of Vagbhata, Bhela Samhitha of Bhela and Kashayapa Samhitha of Vruddha Jeevaka are some of the very famous Ayurveda books.

\section{Internal Arrangement of Ayurvedic Classics}

When reviewing the Ayurvedic classics, authors of major core books in Ayurveda, viz. Charaka, (Charaka Samhitha), Susrutha (Susrutha Samhitha) and Vagbhata (Ashtanga Hardaya Samhitha) and also Acharya Sri Madhavakara (Madhava Nidanaya), Bavamishra (Bhava Prakasha) and Sharangadhara (Sharangadhara Samhitha) have followed several common methods to organize Ayurvedic medical knowledge in Ayurvedic Classics. According to that, it could be seen categorization of Sthanas (Sections) and again the division into Adyayas (chapters). 
Charaka Samhitha comprised eight Sthanas (Sections) and 120 Adhyayas (Chapters). They are Sutra Sthana, Nidana Sthana, Vimana Sthana, Sarira Sthana, Indriya Sthana, Chikithsa Sthana, Kalpa Sthana and Siddhi Sthana. There are six Sthanas (Sections) and 120 Adhyayas (chapters) in the Susrutha Samhitha. These sections are Sutra Sthana, Nidana Sthana, Sarira Sthana, Chikitsa Sthana, Kalpa Sthana and Uttara Tanthra. Uttara Tantra, the last section is not found in the original scheme. It indicates that it was added later on as a supplement. Ashtanga Hardaya Samhitha also contains six Sthanas i.e. Sutra Sthana, Sarira Sthana, Nidana Sthana, Chikitsa Sthana, Kalpa-Sidhi Sthana, and Uttara Sthana. The total number of Adhyayas (chapters) in Ashtanga Hardaya Samhitha is 120.

It is a significant fact that in writing these core books in Ayurveda, authors followed several common features. Thus, all the authors, of the above mentioned classics have divided their texts into Sthanas (Sections) and Adhyayas (Chapters) of whole knowledge of Ayurveda medicine.

\section{Hierarchical Order of Ayurveda Classics}

In addition to this, they expressed their identity by following special methods and arrangements. The authors of major Ayurveda classics, normally used a similar pattern in the organization of medical knowledge. Hence, they divided the context of the books into Sthanas (sections) and Adhyayas (chapters). In addition to this, they expressed their identity by following special methods and arrangements. They have given priority to their own interests and arranged hierarchies in respect of their traditions. As a result of that, Charaka commenced his work in Charaka Samhitha, by giving priority to kaya chikitsa of Sutra Sthana. Susrutha prioritized the section on Shalya and Shalakya by respecting his tradition.

\section{Conclusion}

The Ayurveda system of medicine has flourished in the Eastern world for several decades and has established itself as one of the oldest systems of medicine. Organization of knowledge in Ayurveda system of medicine has some specialized features when compared with knowledge organization patterns which existed in Western and Eastern world during that period. 
This study confirms that the Ayurveda system of medicine has a systematic, methodical and also significant hierarchical way of pattern of knowledge organization. It has therefore to be concluded that the knowledge organization in Ayurveda medicine has been done, not based on any other system available elsewhere or at any other period, but it developed an affiliation in their own identical ways particular to it and is therefore unique.

\section{References}

Charaka (2017). Agnivesha's Charaka Samhitha: Text with English Translation and Critical Exposition based on ChakrapaniDatta's Āyurveda Dipika. Vol. I, (Suthra Sthāna), ed. R.K. Sharma and Bhagawan Dash, Varanasi: Chaukhamba Sanskrit Series Office.

Hjorland, B. (2008). What is Knowledge Organization? Knowledge Organization, 35(3/2), 86-101. Retrieved from: https://www.nomos elibrary.de/10.5771/0943-7444-2008-2-3-86

Hjorland, B. (2013). Theories of Knowledge Organization. Knowledge Organization, 40(3), 169-181.

Kumar, P.S.G. (2004). Knowledge Organization, Information Processing and Retrieval: Theory. Delhi: B.R. Publishing Corporation.

Mai, J.E. (2014). A Postmodern Theory of Knowledge Organization, Denmark; Royal School of Library and Information Science.

Needham, C.D. (1964). Organizing Knowledge in Libraries : An Introduction to Classification and Cataloguing. London: Andre Deutsch Limited.

Oxford Encyclopedic English Dictionary. (1995). $9^{\text {th }}$ edition, ed. H.W. Fowler and F.C. Fowler, Delhi: Oxford Union Press.

Ranganathan, S. R. (1967). Prolegomena to Library Classification. Bombey: Asia Publishing House. 
Rowely, J. (1999). Knowledge Management: Owners of the Knowledge. The Library Association Record, 101(8), 475.

Satija, M.P.A. (2004). Dictionary of Knowledge Organization. Amritsar: Guru Nanak University.

Smiraglia, R.P.(2002). The Progress of Theory in Knowledge Organization. Library Trends Vol.50, No.3, 330-349.

Susrutha (1981). Suśrutha Saṃhitha. Fundemental and Plastic Surgery Considerations in Ancient Indian Surgery. Suthra Sthāna, ed. G.D.Singhal, S.N.Tripathi and G.N.Chaturvedi, Delhi: Chaukhamba Sanskrit Pratishthan. 